\title{
Electronic Properties of Transition-metal Phthalocyanines Obtained within a Hybrid Functional and Bethe-Salpeter Approach
}

\author{
S.V. Syrotyuk*, Yu.V. Klysko \\ Semiconductor Electronics Department, Lviv Polytechnic National University, 12, S. Bandera St., \\ Lviv 79013, Ukraine
}

(Received 21 April 2020; revised manuscript received 15 October 2020; published online 25 October 2020)

\begin{abstract}
The three-stage calculation of the electronic and optical properties of T-phthalocyanine, where $\mathrm{T}=\{\mathrm{Mn}$, $\mathrm{Fe}, \mathrm{Co}, \mathrm{Ni}, \mathrm{Cu}, \mathrm{Zn}\}$, has been performed. On the first stage, the hybrid functional PBE0 of the exchangecorrelation energy was employed. The use of the hybrid functional has enabled us to obtain better energy levels of the semi-core $3 d$ electrons of the T-elements. The crystal wave functions, electron densities, potentials and the electronic energy band spectrum formed the basis for the second stage of the calculations. The second stage was made on the basis of Green's function (GF) approach, namely, on the first order of perturbation theory, called the GW approximation. This approximation clearly takes into account the electron and hole, but only in the static version of their interaction. In the formalism of the GF, we obtained a quasi-particle spectrum of electrons and holes, which agrees very well with the experiment. Therefore, having completed the second stage of the calculations, we have obtained a good basis for performing the third stage, namely for calculating the optical properties of the materials under consideration. The third stage has been done within the Bethe-Salpeter equation (BSE). Within this approach, the electron and hole move, in contrast with PBE0 and GW methods. Optical absorption obtained from the BSE approach illustrates better agreement with measured data for all the materials considered here.
\end{abstract}

Keywords: Nanomaterials, Phtalocianines, PBE0, Green's function, Optical absorption.

\section{INTRODUCTION}

During the last decades, interest to organic dyes has been rising due to the development of organic electronics. Organic dyes and chromophores are small molecular materials, mostly polycyclic aromatic hydrocarbons which are characterized by $\pi$-bonds. These materials are especially attractive for their stability, processability and profitability. Metal-doped phthalocyanines are a group of two-dimensional aromatic compounds with an impurity of metal atom inside (Fig. 1).



Fig. 1 -Molecular structure of the list of investigated molecules: $\mathrm{X}=\mathrm{Mn}, \mathrm{Fe}, \mathrm{Co}, \mathrm{Ni}, \mathrm{Cu}, \mathrm{Zn}$

Copper phthalocyanine $(\mathrm{CuPc})$ is a well-known industrial dye. It is widely studied as a hole transport layer in organic or hybrid heterojunctions [1,2] as well as a donor material in donor-acceptor heterojunctions [3]. Zinc phthalocyanine (ZnPc) is quite similar to $\mathrm{CuPc}$ (both $\mathrm{Cu}$ and $\mathrm{Zn}$ atoms have a fully occupied $3 d$ shell) and is investigated for the same purposes [3-5].
The investigations of magnetic properties of bulk materials showed a paramagnetic behavior in the materials except beta-MnPc and alpha-FePc, where ferromagnetism has been discovered below $10 \mathrm{~K}$ [6]. Also diamagnetic properties have been defined in NiPc. These results are explained by a weak interaction between molecules. Thus, many works present the investigations of single molecule objects or monolayers on different substrates with the aim of control of magnetic properties and perspective of the creation of nanoscale spintronic devices [7, 8].

Our investigation is supposed to examine PBE0 hybrid functional by evaluation of electronic and magnetic properties of the materials within both hybrid and non-hybrid functionals and to obtain quasiparticle properties taking into account excitonic effects.

\section{METHODS}

The exchange-correlation hybrid functional PBE0 is defined by the following equation:

$E_{x c}^{P B E 0}[\rho]=E_{x c}^{P B E}[\rho]+\alpha\left(E_{x}^{H F}\left[\psi_{3 d}\right]-E_{x}^{P B E}\left[\rho_{3 d}\right]\right),(1)$

where $E_{x c} P B E[\rho]$ is the GGA-PBE functional [9]; $E_{x} H F\left[\Psi_{3 d}\right]$ represents the exchange Hartree-Fock energy; $\Psi_{3 d}$ and $\rho_{3 d}$ denote, respectively, the wave function and the electron density of strongly correlated $d$ electrons. In Eq. (1), the coefficient $\alpha$ determines the mixing part of the exact Hartree-Fock exchange and GGA-PBE one.

All the calculations have been performed within the projector augmented wave (PAW) method [10] and ABINIT code [11]. In the ABINIT code, PBE0 functional is implemented for calculations within PAW approach

\footnotetext{
*svsnpe@gmail.com
} 
as the so-called local exact exchange. This means that mixing is performed for $d$-electrons only inside an atomic sphere defined by $r_{c}$.

The summary of PAW options is presented in Table 1.

Unfortunately, ABINIT has some unimplemented features, namely, GW calculation with the hybrid functionals and BSE method for materials with metal occupation.

Thus, we have performed two GW calculations for pure phthalocyanine $\left(\mathrm{H}_{2} \mathrm{Pc}\right)$ and $\mathrm{ZnPc}$ within $\mathrm{PBE}$ functional in order to obtain the so-called scissor energy value which means the difference between GW and GGA energy gaps. This value is needed to perform BSE calculations. For both molecules, this value is the same and equals $1.75 \mathrm{eV}$.

GW eigenvalues have been obtained within standard "one shot" quasiparticle method.

How to avoid the inability to use the BSE approach with metal occupation? First, we perform ground-state calculations within PBE0 functional and metal occupation to define magnetization $\mu$ for each molecule. Then, having compared the values of $\mu$ with the experiment, we set the values of target magnetization (spin $S$ ) for calculations with semiconductor occupation.

For each molecule we have performed calculations with both PBE and PBE0 functionals for zero and nonzero magnetization (for $\mathrm{NiPc}, \mathrm{CuPc}$ and $\mathrm{ZnPc}$ with zero magnetization only) using the semiconductor type of electron occupation. Finally, having obtained wave functions and using scissor energy we evaluated electronic properties within the BSE approach.

BSE calculations have been performed by direct diagonalization of the excitonic Hamiltonian with Tamm-Dancoff approximation (resonant-only).

Having performed the convergence study, we have defined optimal plane wave cut-off energies: 60 Ry for the wave function, $280 \mathrm{Ry}$ for the electron density and potentials and $6 \mathrm{Ry}$ for RPA dielectric matrix. All electronic and optical properties of molecules have been calculated using the basis of states consisting of 190 bands.

Table 1 - The initial options for PAW generation: the cut-off radii $r_{c}$ and valence basis states

\begin{tabular}{|c|c|c|}
\hline Atom & $r_{c}, r_{\text {Bohr }}$ & Valence states \\
\hline $\mathrm{H}$ & 0.9 & $1 \mathrm{~s}^{1}$ \\
\hline $\mathrm{C}$ & 1.3 & $2 \mathrm{~s}^{2} 2 \mathrm{p}^{2}$ \\
\hline $\mathrm{Mn}$ & 2.1 & $3 \mathrm{~s}^{2} 3 \mathrm{p}^{6} 3 \mathrm{~d}^{6} 4 \mathrm{~s}^{1}$ \\
\hline $\mathrm{Fe}$ & 2.1 & $3 \mathrm{~s}^{2} 3 \mathrm{p}^{6} 3 \mathrm{~d}^{7} 4 \mathrm{~s}^{1}$ \\
\hline $\mathrm{Co}$ & 2.1 & $3 \mathrm{~s}^{2} 3 \mathrm{p}^{6} 3 \mathrm{~d}^{8} 4 \mathrm{~s}^{1}$ \\
\hline $\mathrm{Ni}$ & 1.8 & $3 \mathrm{~s}^{2} 3 \mathrm{p}^{6} 3 \mathrm{~d}^{8} 4 \mathrm{~s}^{2}$ \\
\hline $\mathrm{Cu}$ & 2.0 & $3 \mathrm{~s}^{2} 3 \mathrm{p}^{6} 3 \mathrm{~d}^{10} 4 \mathrm{~s}^{1}$ \\
\hline $\mathrm{Zn}$ & 2.3 & $3 \mathrm{~d}^{10} 4 \mathrm{~s}^{2}$ \\
\hline
\end{tabular}

\section{RESULTS AND DISCUSSION}

Let us start the results revision from parameters obtained within PBE0 and with metal occupation. All materials have shown the integral value of magnetization close to the experimental ones, except CuPc (Table 2). A single molecule of $\mathrm{CuPc}$ has no magnetization, while experiments result $S=1 / 2$ for both alpha- and betha$\mathrm{CuPc}$, but alpha-CuPc is paramagnetic and betha-CuPc is diamagnetic. The energy gaps of materials are almost equal, except $\mathrm{CuPc}$ again. Here, $E_{g}$ is slightly higher than half of the mean value for the list of other molecules.

The values of electron energy gap $E_{g}$ obtained with semiconductor occupation are not clear, thus we are going to compare the imaginary part of the dielectric function (DF) $\varepsilon_{2}$ as this parameter is more integrative and informative.

In order to avoid the GW section due to the causes mentioned in the methods section, we have applied the same value of scissor energy $(1.75 \mathrm{eV})$ for all molecules.

Considering $\varepsilon_{2}$ in $\mathrm{MnPc}$ we can notice that the results for ferromagnetic case $(S=3 / 2)$ show better agreement with experimental absorption spectra. This concerns both one-particle (PBE and PBE0) and quasiparticle (PBE-BSE and PBE0-BSE) approaches. But instead of a single peak at the edge of the optical gap, $\varepsilon_{2}$ obtained within BSE has a more complex structure. The most accurate result has been found within PBE0BSE approach for a ferromagnetic molecule $(S=3 / 2)$, whereas $\varepsilon_{2}$ for $S=0$ is shifted up to larger energies.

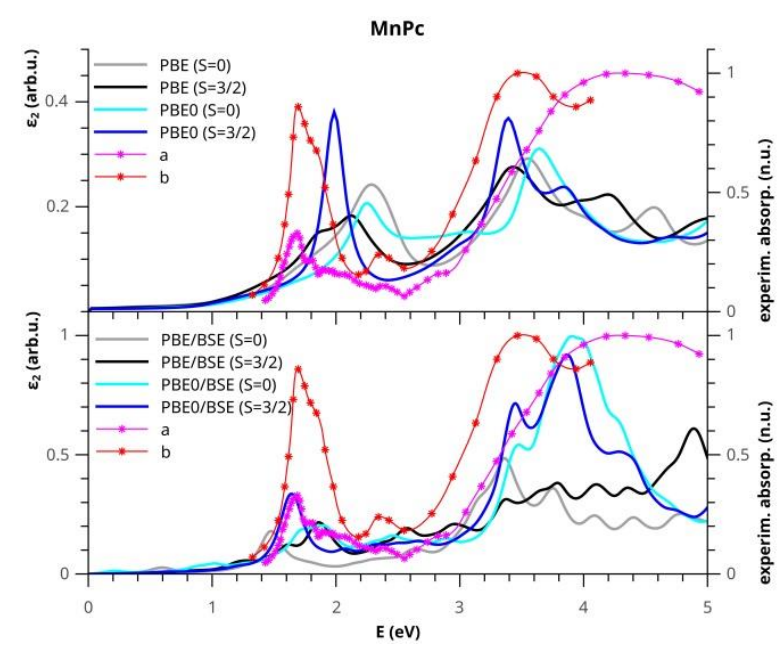

Fig. 2 - Imaginary part of the DF $\varepsilon_{2}$ obtained within RPA and BSE on the base of PBE and PBE0 functionals in the molecule of $\mathrm{MnPc}$ in comparison with experimental absorption spectra: $\mathrm{a}-[12], \mathrm{b}-[13]$

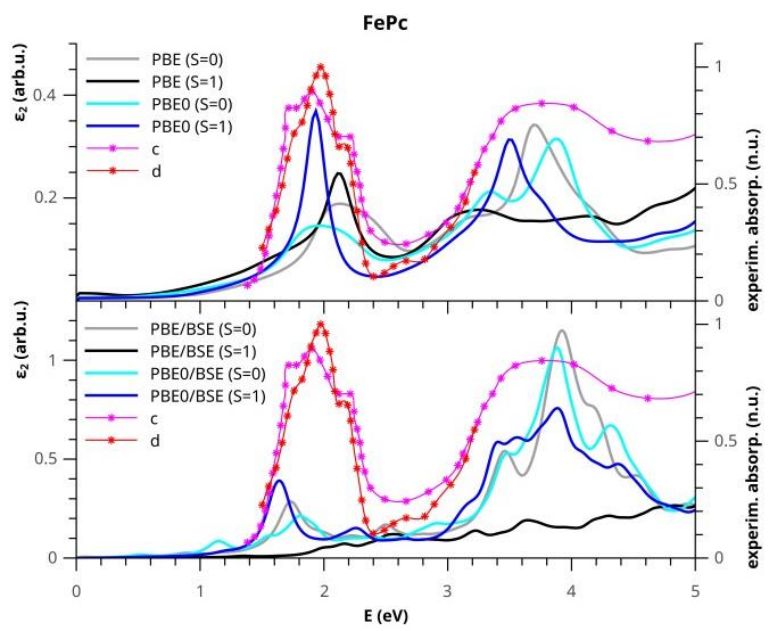

Fig. 3 - Imaginary part of the DF $\varepsilon_{2}$ obtained within RPA and BSE on the base of PBE and PBE0 functionals in the molecule of $\mathrm{FePc}$ in comparison with experimental absorption spectra: c - [14], d - [15] 
In $\mathrm{CoPc}, \varepsilon_{2}$ obtained with $\mathrm{PBE}$ and $S=0$ is shifted approximately by $2 \mathrm{eV}$ towards higher photon energies, that is far away from experimental spectra. In case of PBE and $S=1 / 2$, there is good agreement with experiment. Considering PBE0 we can notice a low difference between $\varepsilon_{2}$ obtained for $S=0$ and $S=1 / 2$. Both PBE0-based $\varepsilon_{2}$ are accurate in comparison with experimental data. Two cases of PBE-BSE based $\varepsilon_{2}$ are not compatible with absorption spectra. The PBE0-BSE results are more accurate but in both cases $(S=0$ and $S=1 / 2) \varepsilon_{2}$ is shifted by $0.2 \mathrm{eV}$ towards lower energies.

In NiPc, both PBE and PBE0 approaches give $\varepsilon_{2}$ which show good agreement with experimental data. However, in this molecule, quasiparticle methods (PBEBSE and PBE0-BSE) are less accurate. In both cases, the first peak of $\varepsilon_{2}$ is shifted down by about $0.5 \mathrm{eV}$ compared with the experimental one.

Similarly to $\mathrm{NiPc}$, in the $\mathrm{CuPc}$ molecule, we can notice the small difference between DFs found within

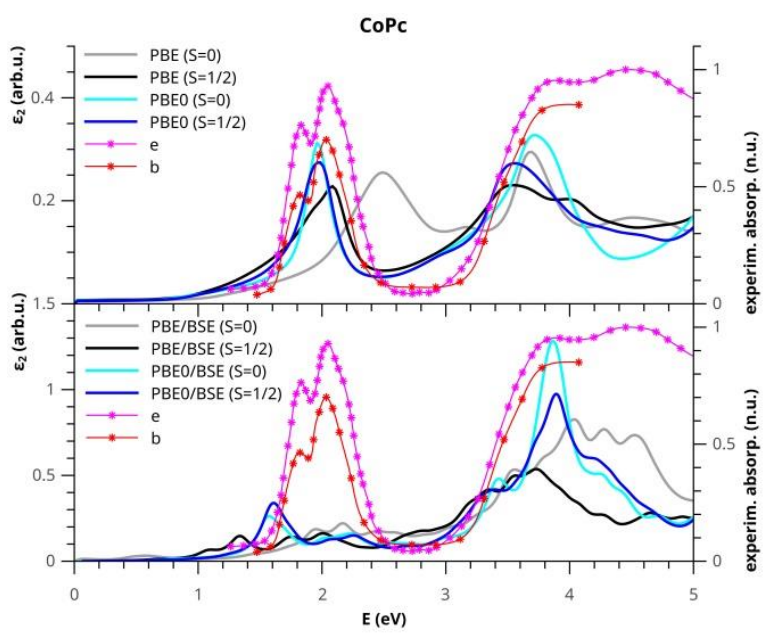

Fig. 4 -Imaginary part of the DF $\varepsilon_{2}$ obtained within RPA and BSE on the base of PBE and PBE0 functionals in the molecule of $\mathrm{CoPc}$ in comparison with experimental absorption spectra: $\mathrm{e}-[16], \mathrm{b}-[13]$

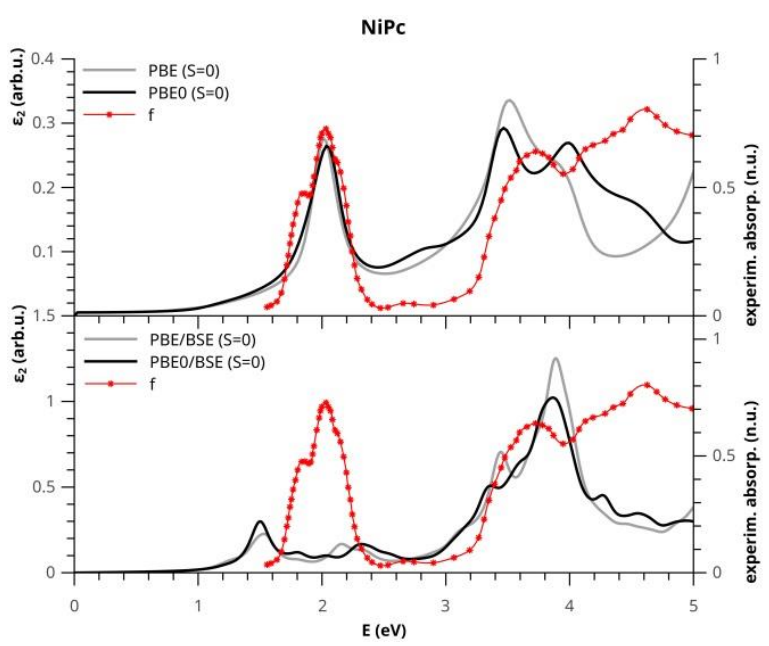

Fig. 5 - Imaginary part of the DF $\varepsilon_{2}$ obtained within RPA and $\mathrm{BSE}$ on the base of PBE and PBE0 functionals in the molecule of NiPc in comparison with experimental absorption spectra: $\mathrm{f}-[17]$



Fig. 6 - Imaginary part of the DF $\varepsilon_{2}$ obtained within RPA and BSE on the base of PBE and PBE0 functionals in the molecule of $\mathrm{CuPc}$ in comparison with experimental absorption spectra: $\mathrm{g}-[18]$

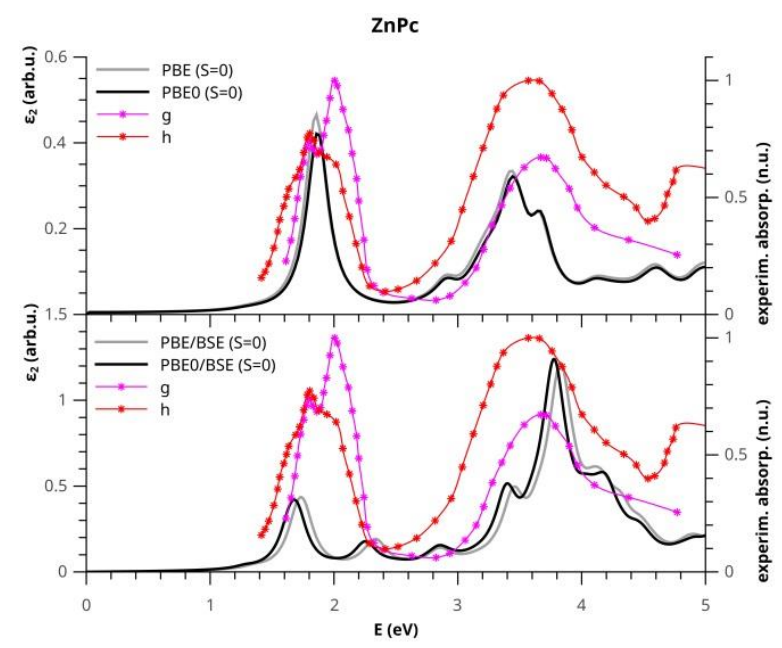

Fig. 7 - Imaginary part of the DF $\varepsilon_{2}$ obtained within RPA and $\mathrm{BSE}$ on the base of PBE and PBE0 functionals in the molecule of $\mathrm{ZnPc}$ in comparison with experimental absorption spectra: $\mathrm{g}-[18], \mathrm{h}-[19]$

the PBE and PBE0 approaches, as well as within the PBE-BSE and PBE0-BSE, respectively. Here, both BSEbased $\varepsilon_{2}$ are shifted down. The difference in the first peak energies between one-particle and quasiparticle approaches is around $0.5 \mathrm{eV}$.

The same is in $\mathrm{ZnPc}$, but here the difference in the first peak energies between $\mathrm{PBE} / \mathrm{PBE} 0$ and $\mathrm{BSE}$ is lower and is around $0.2 \mathrm{eV}$. Theoretical and experimental absorption spectra (Fig. 2-Fig. 7) and oscillator strength (Fig. 8) allow us to reveal the relationship between the maxima of dielectric functions and the dipole transitions that form them.

\section{CONCLUSIONS}

In order to define electronic and optical properties of transition-metal phthalocyanines, we have performed the ground-state calculations with PBE and PBE0 functionals. The exchange-correlation functional PBE 

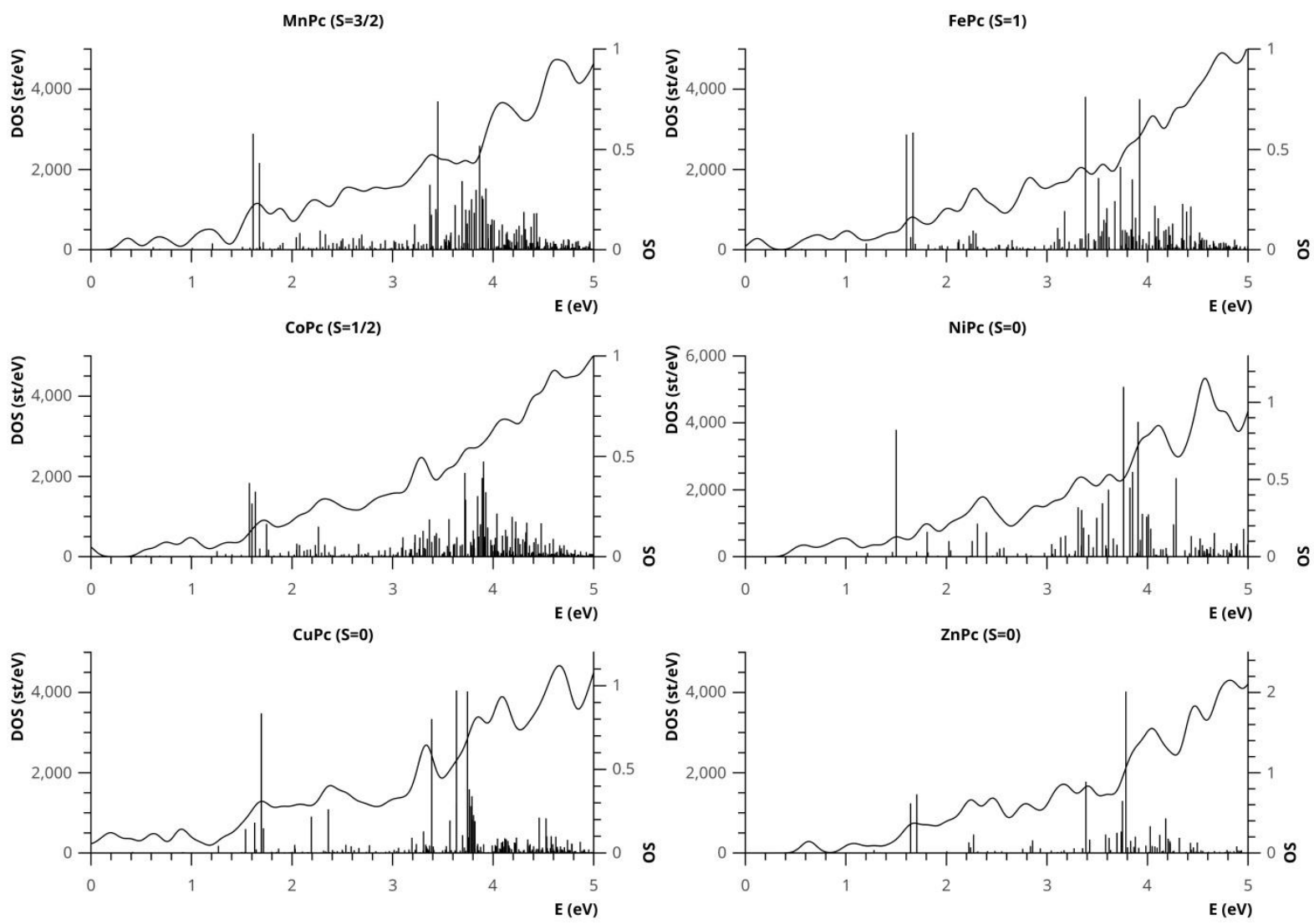

Fig. 8 - Interband density of states (DOS) and oscillator strength (OS) obtained within BSE approach on the base of PBE0 for each molecule. Spin $S$ is given in brackets

Table 2 - The initial options for PAW generation: the cut-off radii $r_{c}$ and valence basis states

\begin{tabular}{|c|c|c|c|c|c|c|c|c|c|c|c|}
\hline & \multicolumn{4}{|c|}{ PBE0 (metallic) } & \multicolumn{4}{c|}{ PBE } & \multicolumn{4}{c|}{ PBE0 } \\
\cline { 2 - 13 } & $E_{g}, \mathrm{eV}$ & $m, \mu \mathrm{B}$ & $S_{\exp }$ & $S$ & $E_{g}, \mathrm{eV}$ & $S$ & $E_{g}, \mathrm{eV}$ & $S$ & $E_{g}, \mathrm{eV}$ & $S$ & $E_{g}, \mathrm{eV}$ \\
\hline $\mathrm{MnPc}$ & $1.38 / 1.04$ & 3.41 & $3 / 2$ & $3 / 2$ & $1.32 / 0.08$ & 0 & $1.47 / 0.39$ & $3 / 2$ & $1.40 / 0.60$ & 0 & $1.42 / 0.33$ \\
\hline $\mathrm{FePc}$ & $1.43 / 1.31$ & 2.00 & 1 & 1 & $1.37 / 0.26$ & 0 & $0.46 / 0.33$ & 1 & $1.34 / 1.21$ & 0 & $1.54 / 0.02$ \\
\hline $\mathrm{CoPc}$ & $1.39 / 0.08$ & 1.09 & 1 & $1 / 2$ & $1.20 / 0.05$ & 0 & $1.42 / 0.89$ & $1 / 2$ & $1.33 / 1.22$ & 0 & $1.39 / 0.22$ \\
\hline $\mathrm{NiPc}$ & $1.41 / 1.41$ & 0.00 & 0 & & & 0 & $1.10 / 1.10$ & & & 0 & $1.38 / 1.38$ \\
\hline $\mathrm{CuPc}$ & $0.76 / 0.76$ & 0.00 & $1 / 2$ & & & 0 & $1.18 / 1.18$ & & & 0 & $0.90 / 0.90$ \\
\hline $\mathrm{ZnPc}$ & $1.35 / 1.35$ & 0.00 & 0 & & & 0 & $1.31 / 1.31$ & & & 0 & $1.31 / 1.31$ \\
\hline
\end{tabular}

does not take into account the strong correlations of $3 d$ states, whereas PBE0 incorporates them by means of the exact Hartree-Fock exchange.

Taking into account the exact exchange and screening (PBE0-BSE) in MnPc leads to more accurate results for the DF in both cases of magnetization value. But DFs obtained with PBE and PBE0 functionals, are seen as one-peak curves, while the experimental data are represented by graphs with a more complex structure.

In FePc, both PBE and PBE0 with two values of $S$ provide an acceptable level of agreement with experi- mental results. The BSE DF reveals a strong dependence on both exchange-correlation functional and spin. Considering the first peak energy, both DFs PBE-BSE with $S=1$ and PBE0-BSE with $S=1$ are more accurate considering the experimental data.

Three molecules with zero magnetization $(\mathrm{NiPc}$, $\mathrm{CuPc}$ and $\mathrm{ZnPc}$ ) show the similar characteristics of the DF. There is a slight difference between exchange-correlation functionals, so $\varepsilon_{2}$ derived with PBE and PBE0 are close enough. The quasiparticle BSE method gives slightly lower excitation energies than experiment.

\section{REFERENCES}

1. T. Lei, H. Dong, J. Xi, Y. Niu, J. Xu, F. Yuan, B. Jiao, W. Zhang, X. Hou, Z. Wu, Chem. Commun. 54, 6177 (2018).

2. Q. Hu, E. Rezaee, Q. Dong, H. Shan, Q. Chen, L. Wang, B. Liu, J.H. Pan, Z.X. Xu, Solar RRL 3, 1800264 (2019).

3. J. Benduhn, F. Piersimoni, G. Londi, A. Kirch, J. Widmer, C. Koerner, D. Beljonne, D. Neher, D. Spoltore, K. Vandewal,

Adv. Energy Mater. 8, 1800451 (2018)

4. F.A. Sarı, M. Kazici, E. Harputlu, S. Bozar, Ö. Koyun, Y. Sahin, N. Ugur, M. Ince, S. Günes, ChemistrySelect 3, 13692 (2018).

5. C.J. Lim, M.G. Park, M.S. Kim, J.H. Han, S. Cho, M.H. Cho, Y. Yi, H. Lee, S.W. Cho, Molecules 23, 449 (2018).

6. J. Yu, Z. Jiang, Y. Hao, Q. Zhu, M. Zhao, X. Jiang, J. Zhao, 
Phys. Condens. Matter. 30, 25LT02 (2018).

7. J. Hu, R. Wu, Phys. Rev. Lett. 110, 097202 (2013).

8. I.E. Brumboiu, S. Haldar, J. Lüder, O. Eriksson, H.C. Herper, B. Brena, B.J. Sanyal, Chem. Theory Comput. 12, 1772 (2016)

9. J.P. Perdew, K. Burke, M. Ernzerhof, Phys. Rev. Lett. 77, 3865 (1996).

10. P.E. Blöchl, Phys. Rev. B 50, 17953 (1994).

11. X. Gonze, F. Jollet, F. Abreu Araujo, D. Adams, B. Amadon, T. Applencourt, C. Audouze, J.-M. Beuken, J. Bieder, A. Bokhanchuk, E. Bousquet, F. Bruneval, D. Caliste, M. Côté, F. Dahm, F. Da Pieve, M. Delaveau, M. Di Gennaro, J.W. Zwanziger, Comput. Phys. Commun. 205, 106 (2016).

12. L. Meng, K. Wang, Y. Han, Y. Yao, P. Gao, C. Huang, W. Zhang, F. Xu, Progr. Nat. Sci.: Mater. Int. 27, 329 (2017).

13. R. Seoudi, G. El-Bahy, Z.E. Sayed, Opt. Mater. 29, 304 (2006).
14. M.M. El Nhass, H.S. Soliman, H.S. Metwally, A.M. Farid, A.A.M. Farag, A.A. El Shazly, J. Optics 30, 121 (2001).

15. K.-J. Huang, Y.-S. Hsiao, W.-T. Whang, Org. Electronics 12, 1826 (2011)

16. A. Gadalla, O. Crégut, M. Gallart, B. Hönerlage, J.-B. Beaufrand, M. Bowen, S. Boukari, E. Beaurepaire, P. Gilliot, J. Phys. Chem. C 114, 4086 (2010).

17. El-Nahass, K.F. Abd-El-Rahan, A.A.M. Farag, A.A.A. Darwish, Int. J. Mod. Phys. B 18, 434 (2017)

18. Z.T. Liu, H.S. Kwok, A.B. Djurišić, J. Phys. D: Appl. Phys. 37, 678 (2004).

19. S. Senthilarasu, S. Velumani, R. Sathyamoorthy, A. Subbarayan, J. Ascencio, G. Canizal, P. Sebastian, J. Chavez, R. Perez, Appl. Phys. A 77, 383 (2003).

\section{Електронні властивості фталоцианінів перехідних елементів, отриманих за методами гібридного функціонала та рівняння Бете-Солпітера}

\section{С.В. Сиротюк, Ю.В. Клиско}

\section{Національний університет "Львівська політехніка", вул. С. Бандери 12, 79013 Львів, Україна}

Виконаний триступеневий розрахунок електронних та оптичних властивостей Т-фрталоціаніну, де $\mathrm{T}=\{\mathrm{Mn}, \mathrm{Fe}, \mathrm{Co}, \mathrm{Ni}, \mathrm{Cu}, \mathrm{Zn}\}$. На першій стадії ми використали гібридний функціонал обміннокореляційної енергії РВЕ0. Використання гібридного функціоналу дозволило нам отримати кращі енергетичні рівні напівостовних $3 d$-електронів Т-елементів. Отримані кристалові хвильові функції, густини електронів, потенціали та електронні енергетичні спектри лягли в основу другого етапу розрахунків. Другий етап був реалізований на основі функції Гріна (GF) у першому порядку теорії збурення, тобто у наближенні GW. Це наближення явно враховуе електрон і дірку, але лише в статичній версії іхньої взаемодії. У формалізмі GF ми отримали спектр квазічастинок електронів $\mathrm{i}$ дірок, що дуже добре зіставляеться з експериментом. Ми отримали добру основу для виконання третього етапу, а саме для розрахунку оптичних властивостей розглянутих матеріалів. Третій етап був реалізований на основі рівняння Бете-Салпітера (BSE). У рамках цього підходу електрон і дірка рухаються, на відміну від PBE0 і GW. Оптичне поглинання, отримане у підході BSE, ілюструе краще зіставлення з виміряними даними для всіх досліджених матеріалів.

Ключові слова: Наноматеріали, Фталоціаніни, РВЕ0, Функція Гріна, Оптичне поглинання. 